\title{
PERFORMANCE AGENT GROUPS IN THE PROMOTION OF SMART ECONOMIC GROWTH
}

Maiga Kruzmetra1, Baiba Rivza², Jonas Jasaitis ${ }^{3}$

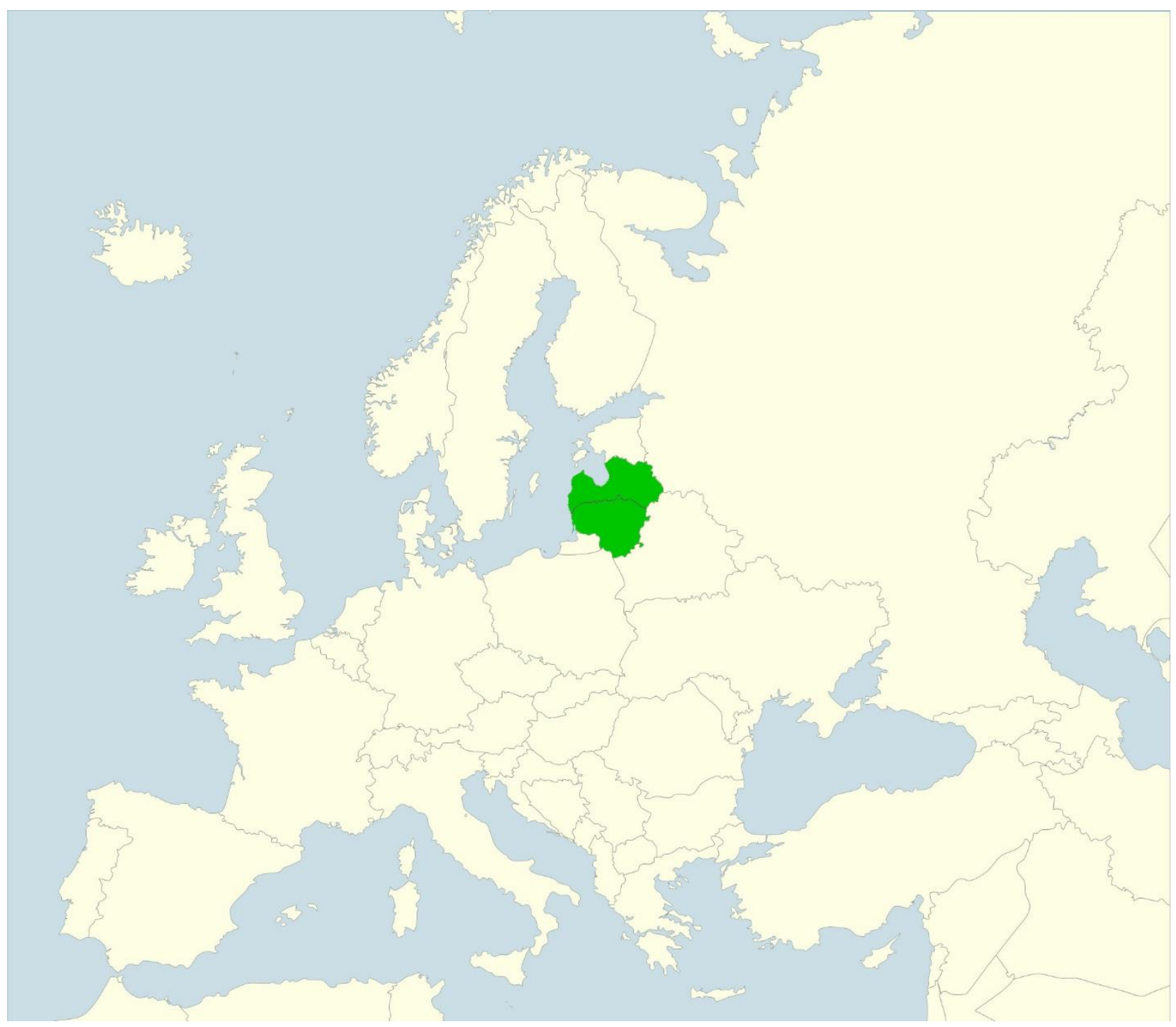

\footnotetext{
${ }^{1}$ Ass. Prof. Dr. hist. Maiga Krūzmētra, senior researcher, Latvia University of Agriculture, Lielā iela 2, 3001 Jelgava, Latvia, email: sala@cs.llu.Iv

2 Prof. Dr. habil. oec Baiba Rivža, Latvia University of Agriculture, Lielā iela 2, 3001 Jelgava, Latvia, email: baiba.rivza@llu.lv

${ }^{3}$ Prof. Dr. soc. sciences Jonas Jasaitis, Faculty of Social Sciences, Šiauliai University, Vilniaus g. 88, 76285 Šiauliai, Lithuania, email: kptc@smf.su.It
} 
Abstract: Any country is interested in economic growth regardless of its development level in any period; yet an increasingly important role in defining growth is played by the term 'smart growth'. The EU development strategy until 2020 defines smart growth as a strategic objective. Smart growth does not take place automatically. It is affected both by the condition of the economic, social and natural environments and by subjective factors - the competence of performance agents. The present research distinguished three groups of rural space and regional performance agents: national institutions, local governments and communities of residents of the territories examined by the research. The research summarised the opinions of experts (Latvia $n=171$; Lithuania $n=163$ ) from the south-eastern part of Latvia and the north-eastern part of Lithuania with the purpose of assessing the contribution of the performance agent groups to the promotion of smart economic growth. The research aimed to identify the positive indications of the contribution made by each performance agent group as well as the largest problems affecting the promotion of smart economic growth in each country. Despite the fact that the sample groups were not representative (did not reflect the views of the entire population), the obtained survey data and the results of this analysis provided insight into the performance agents' action ratings from the bottom-up position and allowed comparing the situations in Latvia and Lithuania. The research has become an urgent task in project No. 5.2.3 "Rural and Regional Development Processes and Opportunities in Latvia in the Context of Knowledge Economy" in National Research Programme 5.2. "Economic Transformation, Smart Growth, Governance and Legal Framework for the State and Society for Sustainable Development - a New Approach to the Creation of a Sustainable Learning Community: EKOSOC-LV".

Keywords: governance, performance, performance agent groups, smart growth.

\section{Introduction}

According to the European Union's smart growth strategy, an increasing role in performance management is assigned to governmental institutions and community-led local development. Governmental institutions have to act as initiators and coordinators for the expansion of innovative activity in their administrative territories. This relates to both national institutions and local authorities that act as institutions administrating local territories. Good quality government institutions may be considered as an essential prerequisite for the development of effective innovation strategies (EC, 2014a). That is why it is of great importance that local governments do have the capacity for this kind of work.

At the same time, the population of local territories are ready for such activities. Community-led local development can mobilise and involve local communities and organisations to contribute to achieving the Europe 2020 strategy goals of smart, sustainable and inclusive growth (EC, 2014b).

Objective processes regarding smart growth and their results in Latvia and Lithuania, which were examined by the present research, have been sufficiently reflected in such internationally important research studies as the Global Competitiveness Index and Policy Performance and Governance Capacities in the OECD and EU countries. The first one covered 138 countries with Estonia being ranked $30^{\text {th }}$, Lithuania $35^{\text {th }}$ and Latvia only $49^{\text {th }}$, getting the lowest rank particularly with regard to innovation and sophistication factors (Global Competitiveness..., 2016). However, the study on policy performance and governance capacities in the OECD countries that covered 41 countries ranked Estonia $12^{\text {th }}$, Lithuania $13^{\text {th }}$ and Latvia only $17^{\text {th }}$ if combining the indicators of policy performance, democracy and governance; Latvia's imperfections concentrated in the field of governance, particularly the provision of executive accountability of governance, which was viewed as a form of capacity for change (Policy Performance..., 2016). One can conclude that overall, the performance of the Baltic States is above average, according to both international reports, yet there are considerable disparities among the countries, and much has to be done 
with regard to progress towards smart economic growth in order to converge with the level of Switzerland, Sweden or Norway.

\section{Theoretical background}

The understanding of the nature of smart development and territories, which is based on innovation and a knowledge-based economy, have been a matter of discussion for a long period. The strategic document "Europe 2020" adopted by the EU in 2010, highlights three key priorities aimed at:

- developing an economy based on knowledge and innovation;

- promoting a more resource efficient, greener and more competitive economy;

- fostering a high-employment economy delivering economic, social and territorial cohesion (“Europa 2020”, 2011).

This strategic economic development direction is continued by a declaration issued by the European Conference on Rural Development (2016), which underlines that an innovative, integrated and inclusive rural and agricultural policy in the European Union should be guided by policy orientations that involve promoting the viability and vitality of rural areas, stimulating knowledge and innovation and raising the governance capacity and efficiency of rural areas (Cork 2.0 Declaration, 2016)

Such growth does not take place automatically. It is affected by both the condition of the economic, social and natural environments and by subjective factors - the competence and motivation of performance agents. Previous research investigations into performance agents have showed that institutions can influence the performance of political and economic systems. Their role is to ensure stable structure, cooperation and collaboration (North D. C., 2004). Governance is viewed as an emerging trend in the public sector, therefore cooperation between institutions and residents has to be seen as attractive (Public Management..., 2009). Governance adaptive to circumstances, which contributes to creative thinking and cognitive synergies, has to be promoted (Ambrosio-Albalá and Bastiaensen 2010)

One of the most essential specifics of governance is the managerial roles and activities to be performed within it, with a focus being placed on leadership activity, which involves innovation and goal-setting, stakeholder mobilisation, delegation of authority or work tasks, as the governance is not only about where to go, but also about who should be involved deciding, and in what capacity. (Governance and...,2000; Graham J. etc. Principles..., 2003). An essential role is also assigned to rating governance processes (Pierre J., 2002), including employing the expert survey method (Vaus D. de, 2014; Jasaitis J., 2014; Jurkènaitè N, 2015).

Research aim. Part of the research that is presented in the paper is not dedicated to the enhancement of theoretical understanding of smart growth but focuses on an evaluation of the activity of performance agents with regard to smart development and smart territorial specialisations based on the outline given in the EC strategic document "Europe 2020". The research distinguished three groups of rural space and regional performance agents: national institutions, local governments and communities of residents of the territories. To perform the evaluation, researchers, $\mathrm{PhD}$ and master degree students, municipality deputies and employees who had a sufficient association with rural development problems were chosen as experts. The research summarised the opinions of the experts (Latvia $n=171$; Lithuania $n=163$ ) from the south-eastern part of Latvia and the north-eastern part of Lithuania with the purpose of assessing the contribution of performance agent groups to the promotion of smart economic growth. The research also aimed to identify the positive indications of the contribution made by each performance agent group as well as the largest problems affecting the promotion of smart economic growth in each country.

For the expert evaluation, the authors defined eighteen situations in which performance agents act or tasks each of them perform, which make effects on innovative, integrated and inclusive rural development (Table 1). The expert evaluation was carried out during 2016. The experts were requested to rate each performance agent's contribution to smart growth as either high, average, 
low or even negative. Descriptive methods and methods for classification were employed to process the data obtained, with the focus being placed on a comparison of percentages of high and low (low/negative) ratings. Such a way of data processing gives an opportunity to identify priority problems for each governance agents taking part in performance processes as well as common national problems.

Tab 1. Criteria for an expert evaluation of the actions of performance agents. Source: author-proposed evaluation criteria

\begin{tabular}{|c|c|c|}
\hline $\begin{array}{l}\text { Performance } \\
\text { agents }\end{array}$ & & Situations or actions towards \\
\hline \multirow{6}{*}{ 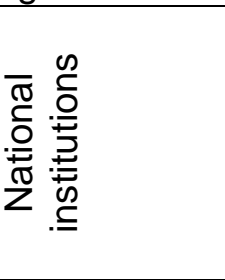 } & 1. & Maintaining a favourable economic situation in the country \\
\hline & 2. & Maintaining the stability of the legislation \\
\hline & 3. & Developing a tax system promoting economic activity \\
\hline & 4. & Availability of EU funding \\
\hline & 5. & Effective performance of the Municipal Finance Equalisation Fund \\
\hline & 6. & Availability of earmarked subsidies \\
\hline \multirow{6}{*}{ 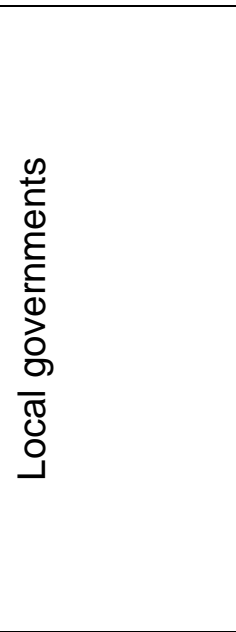 } & 1. & $\begin{array}{l}\text { Skill of the local government to attract and effectively use EU } \\
\text { structural funding }\end{array}$ \\
\hline & 2. & $\begin{array}{l}\text { Purposeful and coordinated activity of deputies in the development } \\
\text { and implementation of a development strategy }\end{array}$ \\
\hline & 3. & $\begin{array}{l}\text { Competence of local government employees in planning the } \\
\text { development of the municipality and in project management }\end{array}$ \\
\hline & 4. & $\begin{array}{l}\text { Results of the implementation of development programmes are } \\
\text { systematically assessed and residents are informed about the results } \\
\text { through direct contacts or the local mass media }\end{array}$ \\
\hline & 5. & $\begin{array}{l}\text { Local governments keep close business contacts with local } \\
\text { entrepreneurs to tackle problems important for both sides }\end{array}$ \\
\hline & 6. & $\begin{array}{l}\text { Local governments create favourable conditions for the activity of } \\
\text { NGOs and other social groups and actively involves them into } \\
\text { discussing and implementing important development problems }\end{array}$ \\
\hline \multirow{6}{*}{ 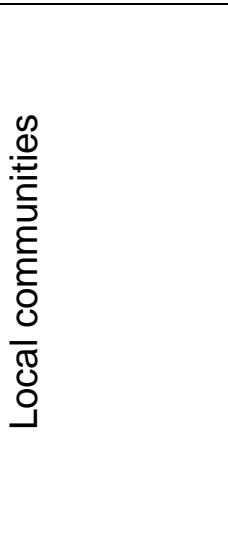 } & 1. & $\begin{array}{l}\text { The wish of local residents to participate in tackling practical } \\
\text { municipality/town problems through active cooperation }\end{array}$ \\
\hline & 2. & $\begin{array}{l}\text { Readiness of residents for economic activities aimed at raising their } \\
\text { incomes }\end{array}$ \\
\hline & 3. & $\begin{array}{l}\text { Readiness of residents for learning and spreading innovative ideas } \\
\text { and changes }\end{array}$ \\
\hline & 4. & $\begin{array}{l}\text { Readiness of residents for gaining new knowledge (through } \\
\text { attending lectures and seminars, taking courses etc.) }\end{array}$ \\
\hline & 5. & $\begin{array}{l}\text { Residents cooperate not only in cultural and sport activities but also } \\
\text { establish economic cooperation networks or even cooperatives }\end{array}$ \\
\hline & 6. & $\begin{array}{l}\text { Communities are ready to accept changes at work, in the society and } \\
\text { environment }\end{array}$ \\
\hline
\end{tabular}

Despite the fact that the sample groups were not representative (did not reflect the views of the entire population), the obtained survey data and the results of this analysis provided insight into the performance agents' action ratings from the bottom-up position and allowed comparing the situations in Latvia and Lithuania.

\section{Research results and discussion}

The processing and analysis of the expert survey data allows drawing a number of important conclusions on the performance of national institutions, local governments and communities of rural areas in respect to the promotion of smart economic growth. 


\subsection{Contribution of national institutions to the promotion of smart economic growth}

The experts rated the contribution of national institutions to the promotion of smart economic growth as quite moderate both in Latvia and in Lithuania. Moderate ratings prevailed for this performance agent group. However, the proportion of low and negative ratings exceeded that of high ratings (Figure 1). In both countries, the highest ratings were given to their skill to make EU funding available (16.3\% of the total ratings in Latvia and $17.2 \%$ in Lithuania). The experts gave the most negative ratings to the tax system. If the numbers of low and negative ratings for the tax system are put together (64.2\% in Latvia and $62.0 \%$ in Lithuania), one can identify a very negative opinion about the activities that are supposed to be aimed at fostering economic growth, criticising, first of all, the persistent change or instability of the tax system.

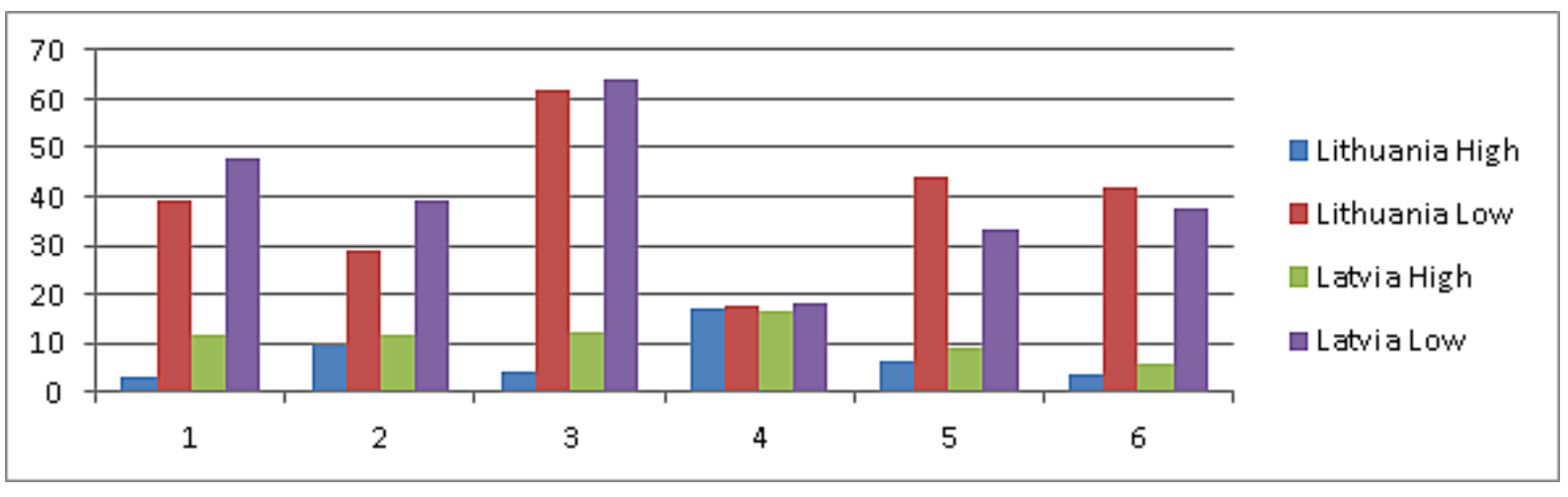

Fig 1. Percentage distribution of the expert ratings of national institutions as a performance agent group. Explanations: 1. Maintaining a favourable economic situation in the country; 2. Maintaining the stability of the legislation; 3. Developing a tax system promoting economic activity; 4. Availability of EU funding; 5 . Effective performance of the Municipal Finance Equalisation Fund; 6. Availability of earmarked subsidies. Source: authors' calculations based on the expert survey

According to the experts, the central government as a system of national-level institutions, on the one hand, contributes to smart economic growth through providing the availability of EU funding, while on the other hand it hinders or even prevents the growth by means of an instable tax policy.

\subsection{Contribution of local governments to the promotion of smart economic growth}

Being the final level of state power, which delegate functions to be performed obligatory, local governments are at the same time a structure that have some autonomy in relation to their administrative territories. This part of autonomy assigns the role of a leader to municipal authorities within their local communities. The experts rated the contribution of local governments to the promotion of smart growth from the latter aspect, which is an important understanding of the nature of the local governments (Pukis, 2010; Jasaitis, 2014; Draskovic and Streimikiene, 2017).

Moderate ratings prevailed for this performance agent group as well. However, compared with the ratings of national institutions, the percentage of high ratings for this performance agent group was higher $(21.7 \%$ in Latvia and $11.2 \%$ in Lithuania). The expert ratings of national institutions as a performance agent group were quite similar in both countries, whereas the expert opinions about local governments differed between the countries. This is proved by the mentioned percentages of high ratings in Latvia and Lithuania. If the numbers of low and negative ratings for local governments are added together, the situation is the same $(21.9 \%$ in Latvia and $37.0 \%$ in Lithuania). 


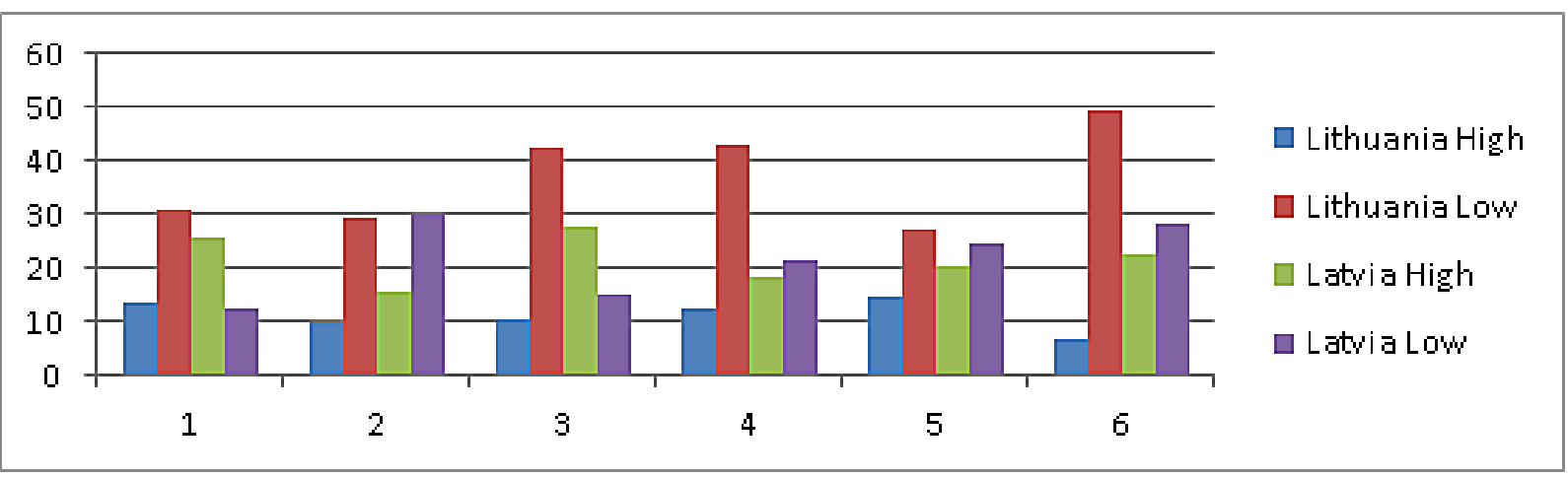

Fig 2. Percentage distribution of the expert ratings of local governments as a performance agent group. Explanations: 1. Skill of the local government to attract and effectively use EU structural funding; 2. Purposeful and coordinated activity of deputies in the development and implementation of a development strategy; 3. Competence of local government employees in planning the development of the municipality and in project management; 4. Results of the implementation of development programmes are systematically assessed and residents are informed about the results through direct contacts or the local mass media; 5 . Local governments keep close business contacts with local entrepreneurs to tackle problems important for both sides; 6 . Local governments create favourable conditions for the activity of NGOs and other social groups and actively involves them into discussing and implementing important development problems. Source: authors' calculations based on the expert survey

For this reason, there are differences in the ratings of individual positions. In Latvia, the experts gave the highest ratings to municipal officials' competence in planning the development of their municipality and in project management $(27.9 \%)$ and to a municipal administration's skills in attracting EU structural funds and effectively using these funds (25.6\%) as the municipal spheres, contributing to progress towards smart growth. In Lithuania, the experts believed that a municipality's close business contacts with local entrepreneurs in tackling important problems for both parties (high ratings totalled 14.7\%) as well as the municipality's skills in attracting EU structural funds and using the funds (13.5\%) were the most important achievements of the municipality.

In Latvia, the experts considered the insufficiently coordinated activity of deputies in designing and implementing the municipality development strategy (the percentage of low and negative ratings was $29.7 \%$ ) and a municipality's insufficient activities to engage social groups in discussing and tackling important development problems of the community $(27.0 \%)$ to be the most critical weaknesses of local governments as a performance agent group. In Lithuania, the experts also believed that a municipality's insufficient activities to engage social groups in discussing and tackling important development problems of the community $(49.6 \%)$ was the greatest problem.

According to the experts, performing no systematic evaluations of the municipality development programme and not informing residents about the results through direct contacts or local mass media (43.0\%) was the next most important problem. The experts gave high ratings to the skilful use of EU structural funding and development planning, whereas the second most important function of municipalities, which is playing the role of a leader for the community and engaging the residents in discussing urgent community matters and, what is even more important, their engagement in achieving the objectives set, unfortunately, were rated very critically.

\subsection{Local communities as promoters of smart economic growth}

The engagement of local communities in making decisions on structural socio-economic changes, land use and development planning is widely practised in European countries. It is also required by EU rural development policies, as sustainable rural development is impossible without viable local communities that actively engage in the promotion of smart economic growth.

The expert ratings of the contribution of rural communities as a performance agent group to smart economic growth, compared with that of national institutions and local governments, brought some changes in the overall rating of this performance agent group as well as in the overall ratings of Latvia and Lithuania as states. The percentages of low and negative ratings in both countries 
increased, particularly in Latvia (40.6\% in Latvia, 32.9\% in Lithuania), compared with the aboveanalysed performance agent groups. The experts gave the highest ratings to rural communities' readiness for economic activities to increase their personal income (the percentage of high ratings was $14.9 \%$ in Latvia, $19.6 \%$ in Lithuania).

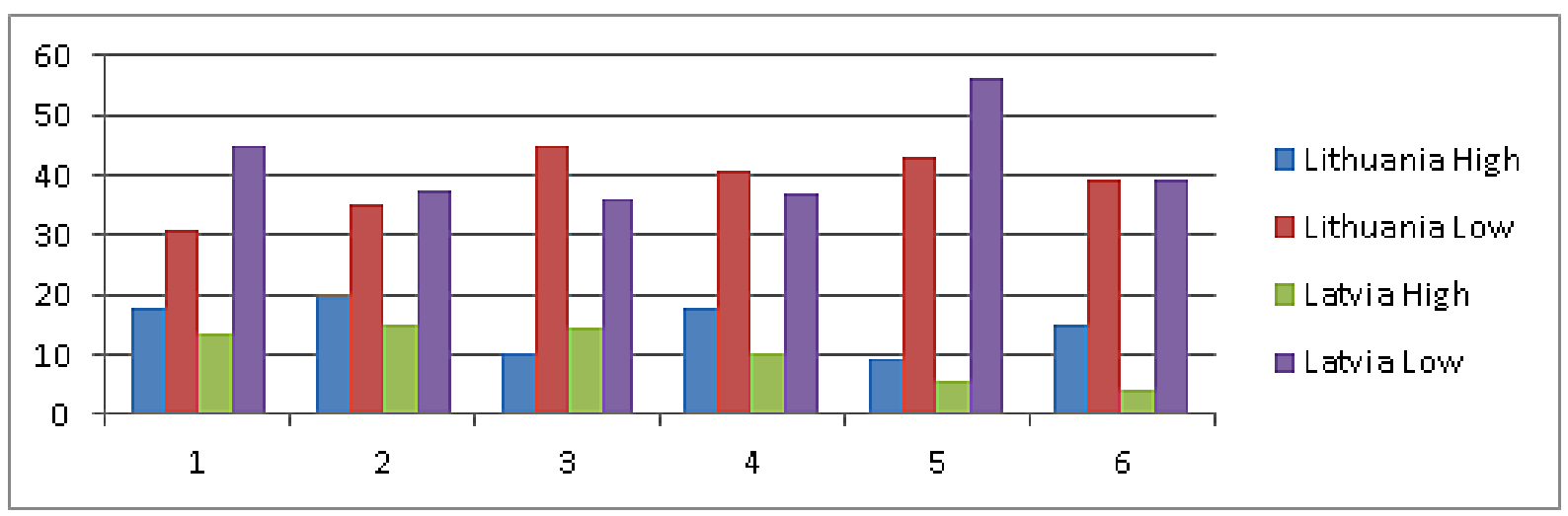

Fig 3. Percentage distribution of the expert ratings of rural residents as a performance agent group. Explanations: 1. The wish of local residents to participate in tackling practical municipality/town problems through active cooperation; 2. Readiness of residents for economic activities aimed at raising their incomes; 3 . Readiness of residents for learning and spreading innovative ideas and changes; 4 . Readiness of residents for gaining new knowledge (through attending lectures and seminars, taking courses etc.); 5. Residents cooperate not only in cultural and sport activities but also establish economic cooperation networks or even cooperatives; 6. Communities are ready to accept changes at work, in the society and environment. Source: authors' calculations based on the expert survey

The percentages of low and negative ratings did not considerably differ between the countries. The readiness of municipality residents to engage in economic cooperation networks or even cooperatives was rated most negatively (the percentage of low and negative ratings was $56.1 \%$ ). Low ratings were also given to the wish of local residents to actively participate and cooperate in tackling practical problems in their municipality (the percentage of low and negative ratings was $44.7 \%$ ). In Lithuania, activities of individual groups of residents to acquire and spread innovative ideas for change (the percentage of low and negative ratings was $44.8 \%$ ) and similarly in Latvia, the wish of local residents to actively participate and cooperate in tackling practical problems in their municipality were rated most negatively (43.0\%).

\subsection{Overall ratings of the performance agent groups with regard to the promotion of smart economic growth}

An analysis of the expert ratings allows summarising the contribution of the performance agent groups, taking into account both positive and negative factors that influenced the promotion of smart economic growth most significantly.

Scientists who have researched governance point out that successful cases of governance and causes and consequences of governance failure have to be studied, and one has to think more about how governance affects collective interests. Poor performance is often explained by a poorly developed institutional framework (Pierre, Graham et al., Vidickiene, 2014, 2016; Melnikiene, 2014).

Tab 2. Main factors influencing the promotion of smart, sustainable and inclusive growth. Source: authors' construction based on the expert survey

\begin{tabular}{|l|l|}
\hline Factors with positive impact & Factors with negative impact \\
\hline * provision of availability of EU funding & * tax system and its instability \\
* municipalities' skills in effectively using the & * local governments do not sufficiently \\
funds attracted & engage social groups in discussing and \\
* communities' readiness for economic & $\begin{array}{l}\text { tackling important development problems } \\
\text { * residents are not ready for economic } \\
\text { activities to increase their personal income } \\
\end{array}$ \\
\hline
\end{tabular}


The available information about the performance agent groups also allows calculating the overall rating for each agent group in both countries by means of the average weighted method.

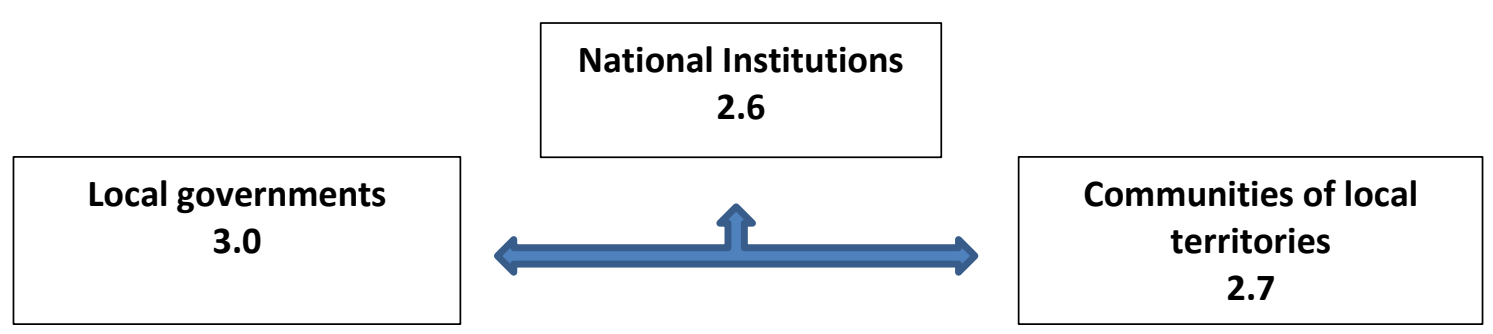

Fig 4. Overall ratings of the groups of performance agents by the Latvian experts (weighted average) (Rating scale: high - 4, medium - 3, low - 2, negative - 1)

According to the Latvian experts, local governments, at least currently, are the most important performance agent group in Latvia, which was rated considerably higher than the other two agent groups. National institutions were rated lower. The rating of the contribution of residents themselves to progress towards smart economic growth was also relatively low. Residents mainly focus on cultural and sport activities, i.e. social activities rather than on building up knowledge needed for economic activity and using the knowledge in practice (Paula, 2015).

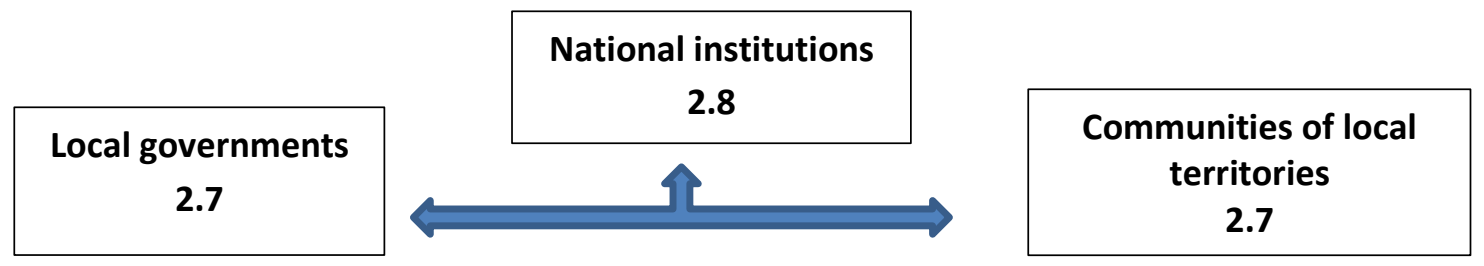

Fig 5. Overall ratings of the groups of performance agents by the Lithuanian experts (weighted average). (Rating scale: high - 4, medium - 3, low - 2, negative - 1)

According to the Lithuanian experts, all the three performance agent groups made almost equal contributions to smart economic growth in the country, with national institutions playing a slightly greater role. A comparison of the ratings for Latvia and Lithuania makes us believe that the equal contributions made by all the three performance agent groups in the neighbouring country resulted in a higher global competitiveness index and higher OECD sustainable governance indicators for Lithuania; besides, in the latter document, all three positions for Lithuania - policy performance, democracy and governance - were rated higher (Jasaitis, 2013, 2014; Kuliešis, Pareigienè, Naus, 2012).

Today, expert opinions have become a widespread method employed for rating social processes (Backstrand, 2003; Littoz-Monnet, 2015; Razafindrakoto and Roubaud, 2010; Vidickienè, Gedminaitè-Raudonè, Vilkè, 2016). An assessment of a territory based on objective data mainly identifies the real situation. An assessment of a territory by experts allows identifying the real situation from the perspective of competent individuals. The method applied by the authors enabled them to acquire ratings of three most important performance agent groups - national institutions, local governments and communities of local territories - and to identify the key ways of enhancement in the promotion of smart economic growth both in the country as a whole and in the territorial units of it.

\section{Conclusions and recommendations}

In each of the country involved in the research, the experts pointed to both similarities and differences in the activity of performance agents. Territorially, both countries lie next to one another and are Member States of the European Union as well as both introduced democratic principles in their governance systems after regaining their independence in the early 1990s. However, the governance processes in their rural areas are different. Therefore, the conclusions stress two trends. 
The first trend refers to the performance agents as governance systems for rural growth. The Lithuanian experts regarded the activity of all the performance agents - national institutions, local governments and residents themselves - as quite coordinated ( $\min -\max =0.1$ points, according to an weighted-average-to-weighted-average comparison), while the highest ratings were given to the contribution made by the national institutions. The opinions of the Latvian experts significantly differed ( $\mathrm{min}-\max =0.4$ points, according to an weighted-average-toweighted-average comparison), and local governments were considered to be the dominant promoter of change. The experts of both countries gave equal ratings to activities of rural residents. This means that the experts had similar views on the participation of rural residents themselves in smart economic growth. However, their views differed with regard to what contributed to this process more - national institutions or local governments.

The second part of the conclusions refers to the evaluation of performance agent actions according to the selected criteria. The experts' ratings convincingly indicated the key tasks for the performance agents, which have not been sufficiently performed until now to promote smart, sustainable and inclusive growth. Since a considerable portion of the ratings of each performance agent were low and negative, an important objective is to achieve an increase in the proportion of high ratings and a decrease in the proportion of low and negative ratings, which is possible if building every performance agent's competences and, as a result, readiness for more intense action. More intense action is particularly necessary within rural communities. Local governments have to mobilise their residents for the purpose of making them aware of unavoidable changes and the need to build up their knowledge to start up and expand smart economic activities, which requires a lot of new knowledge and skills, by providing information and the explanation of it.

To successfully progress towards smart, sustainable and inclusive growth, the authors recommend promoting closer cooperation in the society. In Lithuania, it mainly refers to individuals of rural communities, whereas in Latvia it is true for both performance agent blocks and community members' cooperation in contributing to smart economic growth, thereby balancing their contributions. Research on this problem should be expanded to identify the most optimal conditions and actions that make the greatest contribution to the maintenance of rural viability.

\section{Acknowledgements}

The paper was financially supported by the Latvian National Research Programme EKOSOC-LV.

\section{Academic references}

[1] Ambrosio-Albalá, M. \& Bastiaensen, J. (2010). The new territorial paradigm of rural development: Theoretical foundations from systems and institutional theories [discussion paper]. Antwerpen university.

[2] Backstrand, K. (2003). Civic Science for Sustainability: Reframing the Role of Experts, Policy-Makers and Citizens in Environmental Governance. Global Environmental Politics 3(4), pp. 24-41. DOI: 10.1162/152638003322757916.

[3] Bariss, V. (2009). Publiska administracija. Jelgava: Latvia University of Agriculture.

[4] Bovaird, T. \& Loffen, E., eds. (2009). Public management and Governance. $2^{\text {nd }}$ ed. Abingdonon-Thames: Routledge.

[5] Draskovic, M. \& Streimikiene, D. (2017). Foreword. In Sustainable Development: Crisis or Regulation? (pp. 19-23). Podgorica: ELIT.

[6] Heinrich, C. J. \& Lynn, J. R., eds. (2000). Governance and Performance. New Perspectives. Washington: Georgetown University Press.

[7] Graham, J., Amos, B., Plumptre, T. (2003). Principles for Good Governance in the $21^{\text {th }}$ Century. Policy Brief No. 15. Retrieved: 
http://unpan1.un.org/intradoc/groups/public/documents/UNPAN/UNPAN011842.pdf Access: 10. 01. 2017.

[8] Jasaitis, J. (2014). Alterations of the Role of Non-Urbanized and Low-Urbanized Areas in the Network Society. Review of Research Works. Vilnius: BMK Publishers.

[9] Littoz-Monnet, A. (2015). Ethics Experts as an Instrument of Technocratic Governance: Evidence from EU Medical Biotechnology Policy. Governance 28(3), 357-372. DOI: $10.1111 /$ gove.12102.

[10] North, D. C. (2004). Institutions, Institutional Change and Economic Performance. Cambridge University Press (p. 154).

[11] Paula, L. (2015). Capability of Communities as Precondition for Sustainability of Rural Areas. Proceedings of the 2015 International Conference "Economic Science for Rural Development" No 38 (pp. 103-112). Jelgava, Latvia Agricultural University.

[12] Pierre, J., ed. (2002). Debating Governance: Authority, Steering, and Democracy. Oxford University Press (pp. 241-246).

[13] Pukis, M. (2010). Pašu valdība. Latvijas pašvaldību pieredze, idejas un nākotnes redzējums. Rīga: Latvijas Pašvaldību Savienība.

[14] Razafindrakoto, M. \& Roubaud, F. (2010). Are International Databases on Corruption Reliable? A Comparison of Expert Opinion Surveys and Household Surveys in Sub-Saharan Africa. World Development 38(8), 1057-1069. DOI: 10.1016/j.worlddev.2010.02.004.

[15] Vaus, D. de (2014). Survey in Social Research. $6^{\text {th }}$ ed. Routledge, London and New York, (p. 382).

[16] Vidickiene, D., Melnikiene, R. \& Gedminaite-Raudone, Z. (2014b). Development of Lithuanian Rural Regions Towards Knowledge Society. In Wrzochalska, A., ed., Rural economies in Central Eastern European Countries after EU enlargement (pp. 47-65). Warszawa: Instytut Ekonomiki Rolnictwa i Gospodarki Zywnosciowej.

[17] Zvirgzdina, R. \& Pelse, M. (2012). Development Possibilities of Farms in Latvia. Economic Science for Rural Development Conference Proceedings 28, 133-138.

Other sources

[18] European Commission (2014a). The Role of Government Institutions for Smart Specialisation and Regional Development. IRC Technical reports. IRC. Retrieved: http://ftp.jrc.es/EURdoc/JRC88935.pdf. Access: 9.01.2017.

[19] European Commission (2014b). Community-led Local Development. Cohesion Policy. Retrieved:

http://ec.europa.eu/regional_policy/sources/dicgener/informat/2014/community_en.pf. Access: 5.01.2017.

[20] Keller, J. W (s.a.). The Importance of Rural Development in the $21^{\text {st }}$ Century - Persistence, Sustainability, and Futures. The Regional Institute. Online Publishing. Retrieved: http://www.regional.org.au/au/countrytowns/keynote/keller.htm. Access: 10.01.2017.

[21] Policy Performance and Governance Capacities in the OECD and EU. Sustainable Governance Indicators, 2016. Retrieved: http://www.bertelsmannstiftung.de/de/layer/publikationen/publikation/did/policy-performance-and-governanacecapacities-in-the-oecd-and-eu/.

[22] Global Competitiveness Report 2016-2017 (2016). WEF. Retrieved: https://www.weforum.org/reports/the-global-competitiveness-report-2016-2017-1. Access: 4.01.2017. 